\title{
Nursing Faculty's Evaluations of Technology Integration into the Instructional Setting
}

\author{
Weichieh Wayne $\mathrm{Yu}^{1, *}$, Jenny Wang ${ }^{2}, \&$ Chunfu Charlie Lin $^{2}$ \\ ${ }^{1}$ Department of Nursing, Chronic Diseases \& Health Promotion Research Center, Chang Gung University of Science \\ \& Technology, Taiwan \\ ${ }^{2}$ Department of Applied Foreign Languages, National Formosa University, Yuling County, Taiwan \\ *Corresponding author: Dept. of Nursing, Chang Gung University of Science \& Technology, Chiayi, Taiwan. \\ Tel: 886-5-362-8800. E-mail: jamiemeetsworld@gmail.com
}

Received: April 28, 2013

doi:10.5430/wje.v3n3p24
Accepted: May 14, 2013

URL: http://dx.doi.org/10.5430/wje.v3n3p24
Online Published: May 28, 2013

\begin{abstract}
A descriptive and correctional research was conducted to assess teachers' perceived expertise in using word processing, spreadsheet, and presentation software applications to facilitate instruction in various nursing subjects. The participants were 313 full- and part-time teachers who taught primarily undergraduate classes and possessed necessary knowledge and skills in seven (7) specialized areas in nursing practices, including Fundamental Nursing, Clinical Medicine, Internal Medicine/Surgery, Intensive Care, Public Health/Palliative Care, Psychiatrics, and Obstetrics, Gynecology \& Pediatrics. The findings indicated that the majority of the participants indicated that they did not feel competent in using word processing, spreadsheet, and presentation applications to facilitate instruction on daily basis. Teachers also expressed that they felt some competence in the word processing area, but little competence in presentation and spreadsheet applications. The weaknesses identified areas where professional training might be beneficial. In addition, the significant differences in perceived skill competence based on age suggested that any training should accommodate and address the impact of age as related to technology training. It is recommended that training which involves peer-to-peer learning, collaborative activities, a variety of training materials, and a skilled trainer can provide a learning environment in which individual differences can be accommodated.
\end{abstract}

Keywords: technology integration; computer-facilitated teaching/learning; nursing faculty's perceptions

\section{Introduction}

Computers were initially introduced in the Taiwanese health care system in the early 1970s for administrative and academic research purposes. Since then, computer technologies have been becoming much more powerful and widely used in day-to-day patient care in terms of data input, retrieval, manipulation as well as distribution. As new instructional technologies emerge, most educational institutions that provide essential nursing education to prospect nurses struggle to make these technologies available to their teachers. In Taiwan, continuing studies have been conducted to monitor and evaluate the impact and/or effectiveness of computer use in nursing education. However, the researchers observed that little or no effort is made by administrators to evaluate the technology expertise of the teachers who will be responsible for integrating technologies into the instructional environment (Jiang, Chen \& Chen, 2004; Lee, 2005; Yang \& Lin, 2010). Not only is it important that teachers have expertise in using technologies, they must also be able to integrate them into the instructional setting so that they foster meaningful learning. 


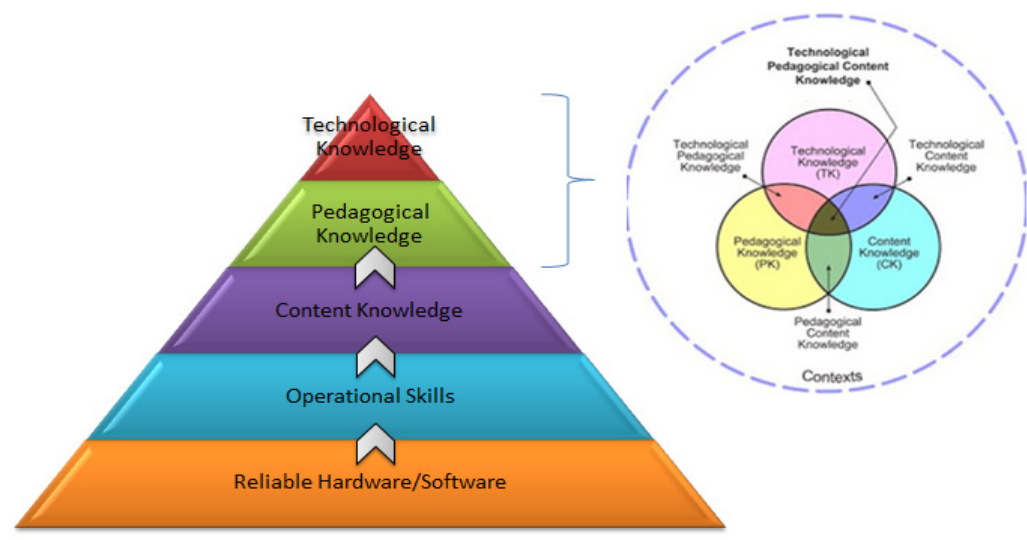

Figure 1: Technology Infusion Model (TIM)

School administration normally follows a technological infusion model (TIM, in Figure 1, adapted from Shulman, 1986) in support of technology integration in instruction. Teachers are supplied with reliable hardware/software and minimum operational skills. It is hoped that they could attain technological pedagogical content knowledge over the course of their professional career. Few schools evaluate teachers' actual or perceived technology competence. In most cases it is assumed that teachers keep up to date through advanced education, training, and experience. Facilitating instruction using technology is a process that encompasses several steps. Its most basic steps include presenting the technology, practice using the technology, feedback from the teacher or others, and application of the technology in a realistic setting. However, teachers' use of technology to support instruction may be hampered without having the competence to use technology themselves, including the knowledge and the ability to use appropriate pedagogical principles to implement technology integration (Okojie, Olinzock, and Boulder, 2006).

A report from the National Center of Educational Statistics (NCES, 2002) indicated hat about a third of the school teachers in the Unites States are not adequately prepared to use computers and the Internet to facilitate instruction. The report also indicated that less experienced teachers feel more positive in implementing computer technology than those with more teaching experience. The more experienced teachers are, in most cases, the older teachers. While it is acknowledged that younger teachers are more familiar with technology, it is important to recognize the need to collect data on how all teachers perceive their ability to use and integrate technology in the classroom setting.

Ronnkvist, Dexter and Anderson (2000) reported that teachers need assistance with both technical support and in instructional delivery to ensure effective implementation of technology integration. Schools cannot hope to improve the academic achievement of their students or the overall value of their programs without quality technology integration. As Donahoo and Whitney (2006) remarked, no educational institution can really make progress in their various programs without successful technology integration by teachers who provide instruction.

Word processing, spreadsheet, and presentation software applications have become necessary skills in today's teaching, learning, and research environments. For technology to be successfully integrated into teaching and learning, teachers do not only need to understand the basic skills, but they also need to understand how (methods/techniques) technology can be integrated into the curriculum (Baylor \& Ritchie, 2002; Becker, 2001; Roberts 2003). According to Becker (2001), “... the ways that teachers have their students use computers are certainly affected by their own level of technical expertise" (p.4).

\subsection{Rationale}

In order to provide appropriate technology training for teachers and trainers, educators must know how these individuals perceive their skill competence and their ability to integrate software applications into the teaching and learning environment. Quite often educators assume that they know what teachers and trainers need as they prepare materials for professional development training. The current researchers believe that in many cases this has contributed to lack of notable success in technology integration. Understanding needs through research initiatives will provide opportunities for teachers and trainers to be involved in their training because, as Knowles, Holton, and Swanson (1998) argued:

...adults resent and resist situations in which they feel others are imposing their wills on them. In spite of their need for autonomy, previous schooling has made them dependent learners. It is the job of the adult educator to move adult students away from their old habits and into new patterns of learning where they become self-directed, taking responsibility for their own 
learning and the direction it takes (p.65).

According to Fullan (2001), educational technology failed because integrating technology into teaching and learning did not take into consideration the cultural climate of schools. Perhaps, each individual school might do well to consider school climate culture as they implement technology integration.

\subsection{Research Questions}

The following questions guided this study.

1) What are the nursing faculty's perceived skills to facilitate instruction using word processing, presentation, and spreadsheet software applications in teaching various nursing subjects?

2) Are there any meaningful relationships, based on gender, among teachers in their perceived skills to facilitate instruction using word processing, presentation, and spreadsheet software to facilitate instruction?

3) Are there any meaningful relationships, based on age, among teachers in their perceived skills to facilitate instruction using word processing, presentation, and spreadsheet software to facilitate instruction?

\section{Theoretical Framework}

Computer technology permeates all aspects of our economic and social lives, including educational practices. Educational institutions strive to make technology the center piece of their instructional tools. The challenge to integrate technology into the classroom continues to be an on-going concern. Since teachers direct classroom activities; teacher education, too, must address the integration of technology in the learning environment. Many school systems have invested large sums of money to provide technology training sessions and workshops for teachers. Woodbridge (2004) explained that computer technologies have been considered education tools for over 40 years. During these years, public school systems, state and federal governments have spent billions of dollars to integrate technology into teaching and learning (Franklin, Turner, Kariuki, \& Duran, 2001). Zuniga (2010) pointed out that United States Office of Management and Budget spent over \$2.8 billion from 2002 through 2007 on technology infusion. Similarly, he pointed out teachers have the desire to use technology to facilitate instruction but lack of experience and lack of knowledge of technology integration inhibited their desire to do so (use technology to support instruction).

Littrell, Zagumny and Zagumny (2005) argued that teachers are not yet in a position to use technology effectively for teaching and learning. Before it can be possible to determine whether technology integration is effectively implemented in the public schools, more research studies are needed to determine teachers' needs in terms of technology training. Technology integration is not a static concept, but rather it is transformational; it changes as knowledge grows.

Discussing some of the views expressed by teachers on technology infusion, Zuniga (2010) stated that out of the 30 teachers who participated in his qualitative research, nine $(30 \%)$ rated their computer skills between one and three on a ten-point scale, with one being the lowest and ten the highest. Zuniga reported that a rating in this range indicated that these teachers were hesitant in using computers for instruction. Eight out of the 30 participants rated their computer knowledge between four and seven, a rating that indicated moderated use; while 13 rated their knowledge between eight and ten which showed that they considered themselves knowledgeable in using computers. According to Zuniga, one teacher who participated in the qualitative study indicated that her school explained the importance of computers in education and encouraged teachers to use computers for instruction, but the teacher maintained that there was no evidence that computers were being used in the classrooms. Also Zuniga reported that another teacher admitted that computer resources were available for use in the classrooms, but she did not use them because she did not know how to use computers effectively in aid of her instruction. The views expressed by these teachers showed that the availability or lack of availability of computer technologies in the classrooms was not the only obstacle to technology integration. Teachers need regular training and frequent encouragement and reinforcement if technology integration is to be successful. The availability of classroom computers, alone, does not ensure that technology integration will take place.

Wilmore and Betz (2000) argued that "information technology will only be successfully implemented in schools if the administration actively supports it, learns as well, provides adequate professional development and supports his/her staff in the process of change" (p.15). The study of Zhao and Bryant (2005) indicated that teachers believed that technology mentorship and follow-up training have helped them (teachers) to "move beyond basic personal use of word processing and the Internet to more complicated use of computer technology, including advanced functions 
in word processing and programs such as Excel, Publisher, and PowerPoint..." (p.57).

The importance of technology integration training and follow-up activities cannot be over-emphasized. However, it is equally important to recognize that technology trainers understand the technology needs of the trainees prior to training. It is believed that technology integration training could be more effective if the focus is on the trainees and what they need rather on the trainers and what skills they can provide. This is echoed by teachers involved in the qualitative study carried out by Zhao and Bryant (2005):

"It was easier [to integrate technology] because I could tell her what we're studying and she would give suggestions. Then we would come up with a plan."

"This has been infinitely different because of the one-to-one help I received from TIS [the specialist]. A difference also existed in the fact that there was an immediate chance to try new skills with real-life students in a classroom setting."

"It allows more flexibility and a chance to focus on specific student/teacher needs rather than just a general lesson that works for some and not at all for others."

"Technology support is far more beneficial than taking a general class."

This study was designed to assess teachers' perceived skills in using word processing, presentation, and spreadsheet software applications as teaching tools and how these applications could be infused into instruction. It also sought to determine if differences exist among teachers perceived skills based on gender and age. Casey and Rakes (2002) explained that teachers who receive continuous training are more likely to use technology to facilitate instruction than those who receive infrequent technology integration training. The findings can be used to assist individuals in developing appropriate instructional materials that addressed teachers' needs and weaknesses. A secondary purpose of this study was to determine if differences exist among teachers in their perceived skill in implementing technology integration based upon gender and age.

\section{Methodology}

\subsection{Research Design}

This quantitative study involved a combination of descriptive and correlational research. The participants' background, demographic profiles, and perceptions of technology integration in an instruction setting were recorded descriptively. A correlational (associational) design was also used to help investigate the possible relationships between the variables under study. In this study, the variables were: 1. gender 2. age 3. teachers' perceived abilities to integrate technology in the classroom setting.

\subsection{Respondents}

The accessible population for the study was approximately 353 full- and part-time nursing teachers in a Taiwanese Nursing Institute during the 2010-2011 academic year. The faculty taught primarily undergraduate classes and possessed necessary knowledge and skills in seven (7) specialized areas in nursing practices: Fundamental Nursing, Clinical Medicine, Internal Medicine/Surgery, Intensive Care, Public Health/Palliative Care, Psychiatrics, and Obstetrics, Gynecology \& Pediatrics. The researchers used a convenient sampling technique to select the subjects for the study. In the end, 313 teachers participated in this study. The participants varied in their age, gender, positions, as well as their experience of using computers for instruction.

\subsection{Instrumentation}

A self-report survey was used to collect data for this study to identify participants' perceptions of technology integration into the instructional setting. The instrument was developed by the researchers based on information obtained from the review of literature in the area of teaching/learning in the online/classroom settings (Kern, 2006; Kenny, 2000; Kimball, 1998; Mazdayasna \& Tahririan, 2008). The questionnaire was made available monolinqually in faculty's native language, Mandarin Chinese in order to avoid receiving any false response due to misinterpretations of the item(s). The questionnaire was divided into two sections. First section was used to gather demographic information, and the subsequent section was used to collect data on teachers' perceived skills in integrating software applications. The questionnaire used for this study contained 30 items in a 5-point Likert scale format, with number 1 being Strongly Disagree (SD), number 2 being Disagree (D), number 3 being Undecided (U), number 4 being Agree (A), and number 5 being Strongly Agree (SA). 


\subsection{Validity and Reliability of the Instrument}

In order to establish the content (face) validity of the instrument, which was stated by Gay, Mills, \& Airasian (2006) as the instrument measuring what it is intended or what it claims to measure, the researchers presented it to a panel of three experts in the field of computer mediated instruction/learning, teaching pedagogy, and statistical analysis, who were asked to validate the content of the survey instrument by ensuring the overall inclusiveness of all the variables under investigation. The experts were also asked to review the survey for things such as unclear instructions, confusing, ambiguous or repetitive items, and overly complex or difficult sentence structure. The researchers then revised the instrument based on the constructive feedback received from the reviewers.

To establish the reliability of the survey instrument used, the researchers employed a test/retest method using 30 students, the number of students in a regular class size. These students were not the subjects for this reported study. The identical survey was completed by the participants twice. There was a waiting window of one week between the first and second administration of the instrument. There was a strong association between the two tests with a correlation coefficient of .78. In addition to the test/retest method, the researchers also performed Cronbach's Alpha reliability test. Cronbach's Alpha value was $\mathrm{r}=85, \mathrm{p} . \leq .05$.

\subsection{Data Collection, Procedures \& Analyses}

The researchers received permission from the head of the Department of Nursing for teachers to complete the questionnaire. Voluntary participation was ensured both through explicit verbal and written explanations. The participants could withdraw from the study at any time. A paper format questionnaire was administered, which took about 15 to $20 \mathrm{~min}$ to complete. They were encouraged to fill out all aspects of the questionnaire. The respondents gave their consent by completing and returning the questionnaire. Data was analyzed using mean scores, percentages, t-test, ANOVA including Turkey HSD Post hoc tests. A T-test was used to determine if statistical significant differences existed between female and male participants in their responses to questionnaire items used in this study. An ANOVA was used to determine if differences existed among groups of participants based on eight (8) age groups. HSD Post hoc tests were used to determine where difference existed among the groups represented in the study.

\section{Results}

\subsection{Description and Computation of Scores for the Scale}

A five-point Likert scale was used to allow the participants to express their perceptions in the areas under investigation, with number "1" being Strongly Disagree (SD) , number "2" being Disagree (D), number "3" being Undecided (U), number "4" being Agree (A), and number "5" being Strongly Agree (SA).

\subsection{Demographic Information}

\subsubsection{Age}

As shown in the Table 1, the youngest participant was 24 years old, with the oldest participant being 63 . The mean age of the students in this study was 39.13 years with a standard deviation of 0.89 years. Figure 2 illustrates the number of teachers grouped by age. Teacher participants in age groups 36 40 years, 51 55 years and 56 years and up accounted for nearly half of the sample size.

Table 1: Descriptive Statistics Based on Age

\begin{tabular}{ccccc}
\hline N & Minimum & Maximum & Mean & Std. Deviation \\
\hline 313 & 24 & 63 & 39.13 & 0.89 \\
\hline
\end{tabular}




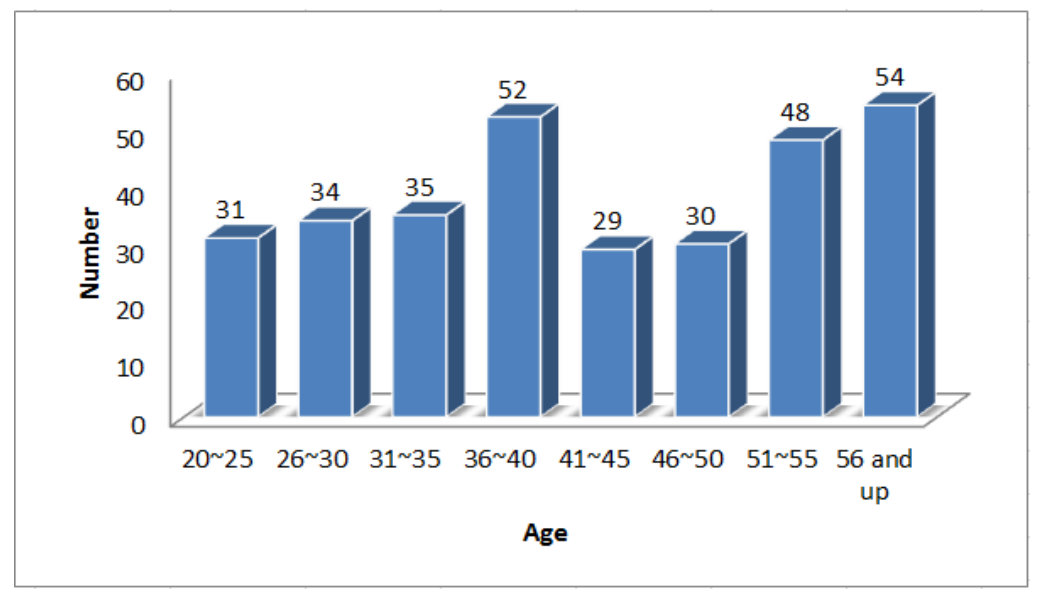

Figure 2: Number of Participants Grouped by Age

\subsubsection{Gender}

As shown in Figure 3, the majority of the participants were female nursing faculty, accounting for nearly $71 \%$, or 222 persons whereas the remaining $29 \%$ or 91 , were males.

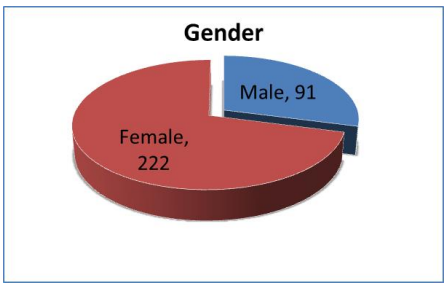

Figure 3: Analysis of the Participants by Gender

As shown in Table 2, nearly one quarter of the participants were members of Psychiatrics and Fundamental Nursing accounted for 1/5, and Clinical Medicine and Intensive Care each had less than ten percent of representation in the study.

Table 2: Analysis of the Participants by Specialized Areas

\begin{tabular}{llc}
\hline Expert Areas & No. of Faculty & $\mathbf{\%}$ \\
\hline Fundamental Nursing & 66 & 21.09 \\
Clinical Medicine & 26 & 8.30 \\
Internal Medicine/Surgery & 40 & 12.78 \\
Intensive Care & 29 & 9.27 \\
Public Health/Palliative Care & 46 & 14.70 \\
Psychiatrics & 70 & 22.36 \\
OB/GYN, Pediatrics & 36 & 11.50 \\
Total & 313 & 100 \\
\hline
\end{tabular}

Figure 4 was used to describe participants' experience (number of years) using computer technology for classroom instruction grouped by 7 expert areas. It was reported that $65.5 \%$, or 205 nursing faculty members, had used computers in teaching from 6 to 10 years (red shaded area in the table). 


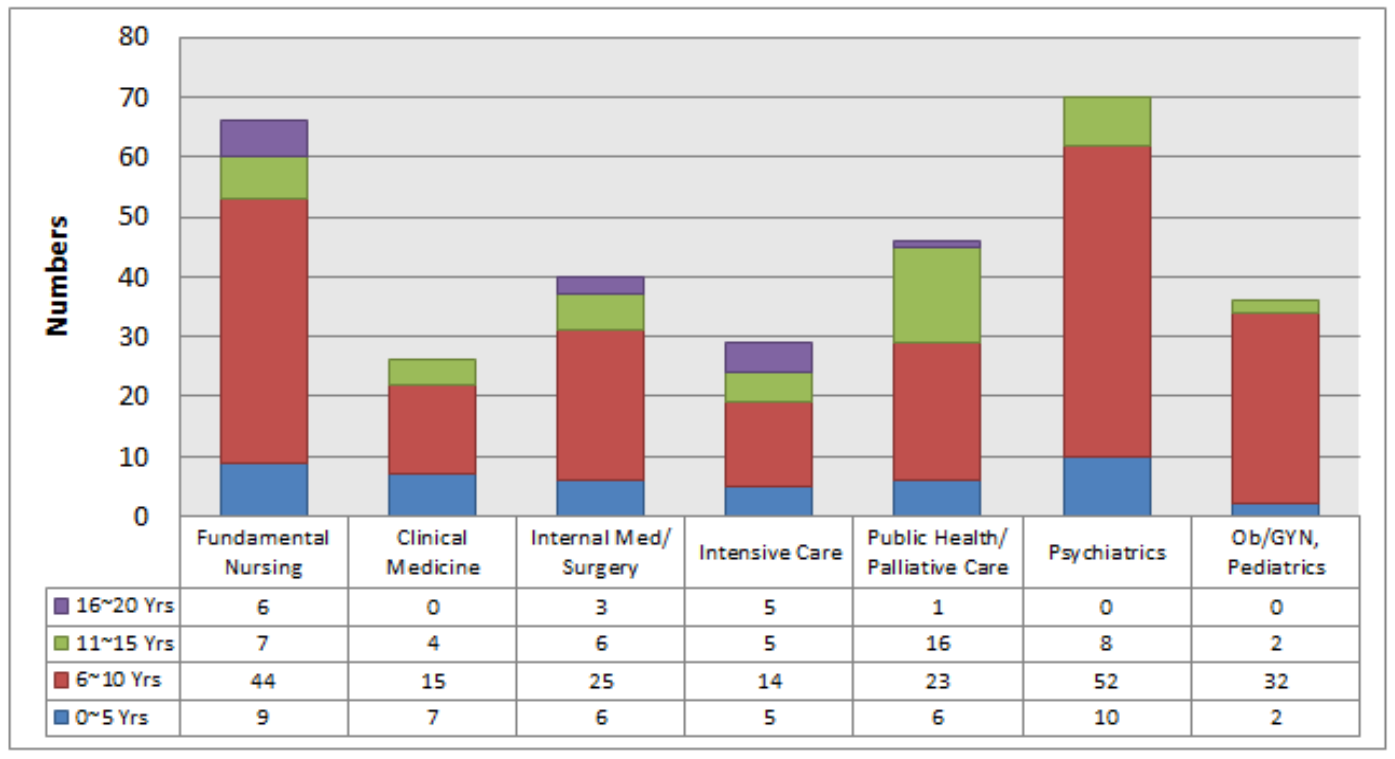

Figure 4: Participants’ Experience of Using Computer Technology for Instruction

\section{Research Question 1}

Research Question 1 stated: What are the nursing faculty's perceived skills to facilitate instruction using word processing, presentation, and spreadsheet software applications in teaching various nursing subjects?

Table 3 was used to interpret the participants' mean scores for the items on the survey instrument. Participants' mean score for each item on the survey is shown in Figures 5 7. The results show that the participants did not perceive that they possessed the competence to complete the application tasks listed on the survey; they reported Undecided or Disagree ratings for 16 items contained in the survey. Except for Word processing, in which the overall mean score fell within the "Agree" range (3.6 out of 5), the mean scores for both Presentation and Spreadsheet software were in the "Undecided" range (3.4 vs 3.16 respectively).

Table 3: Interpretation of Likert Scale Mean Score Values

\begin{tabular}{cc}
\hline Scale & Description \\
\hline $1.00-1.49$ & Strongly Disagree \\
$1.50-2.49$ & Disagree \\
$2.50-3.49$ & Undecided \\
$3.50-4.49$ & Agree \\
$4.50-5.00$ & Strongly Agree \\
\hline
\end{tabular}

As far as Word processing is concerned, the highest mean score, 4.29, was for Question 1: I am able to teach students how to create documents using word processing software. The lowest mean score, 1.90, was for Question 2: I am able to teach students how to format documents using word processing software. (see Figure 5) 


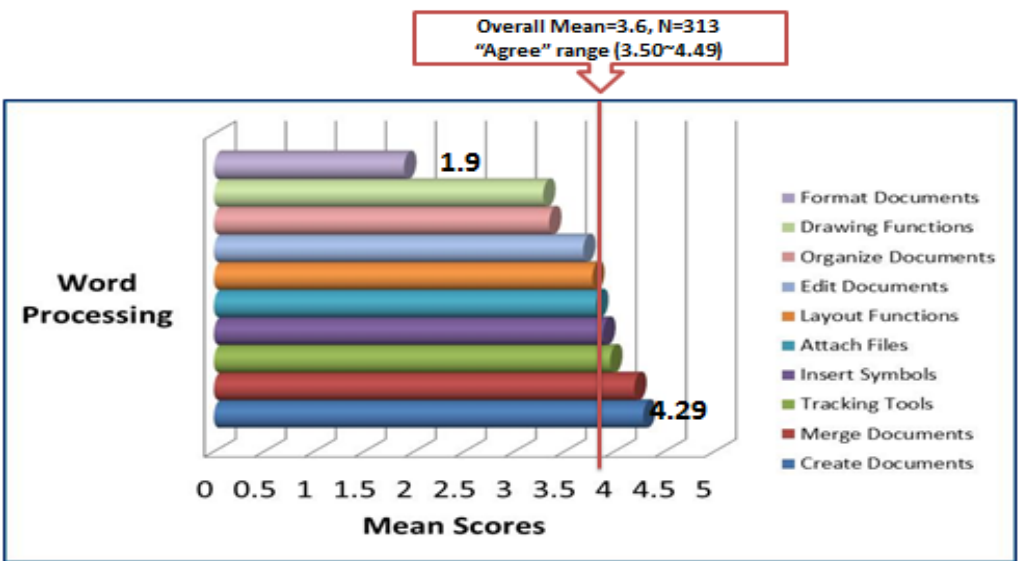

Figure 5: Mean Scores for Items Used to Facilitate Instruction (Word Processing)

In terms of Presentation software, the highest mean score, 3.72, was for Question 11: I am able to teach students how to properly use presentation software. The lowest mean score, 2.40, was for Question 19: I am able to teach students how to link slides to the hypermedia, including the Internet. (see Figure 6)

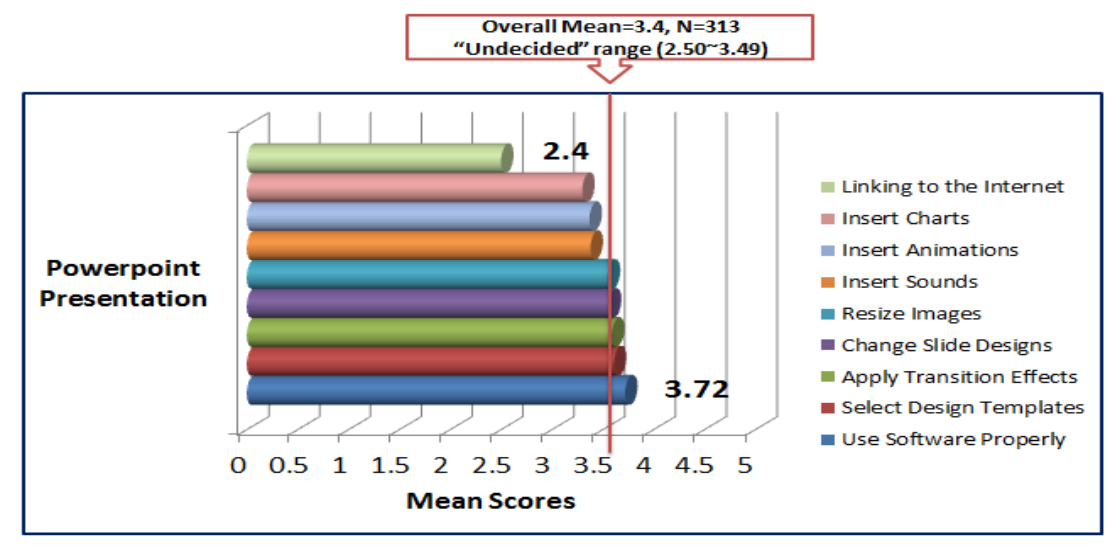

Figure 6: Mean Scores for Items Used to Facilitate Instruction (Powerpoint Presentation)

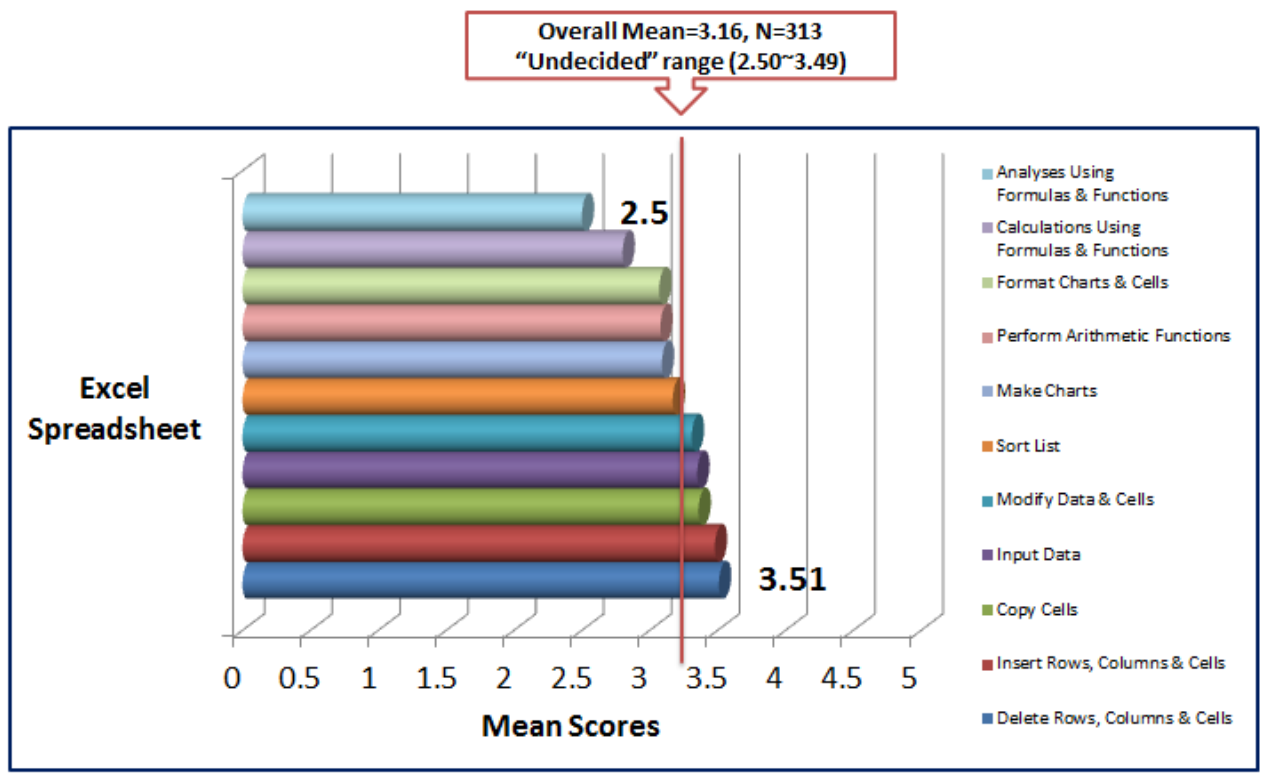

Figure 7: Mean Scores for Items Used to Facilitate Instruction (Excel Spreadsheet) 
The highest mean score, 3.51, was for Question 20: I am able to teach students how to delete rows, columns, and cells in Excel Spreadsheet. The lowest mean score, 2.50, was for Question 30: I am able to teach students how to perform analyses using formulas and functions. (see Figure 7)

Research Question 2

Research Question 2 asked: Are there any meaningful relationships, based on gender, among teachers in their perceived skills to facilitate instruction using word processing, presentation, and spreadsheet software to facilitate instruction?

Female respondents had higher means scores in questionnaire items 1, 3, 5, 6 and 7 using Word Processing software, than their male counterparts shown in Table 4. For question 2, male participants rated their ability higher than female participants. There were no statistical significant differences related to presentation or spreadsheet software applications based on gender.

Table 4: T tests for Word Processing Questions

\begin{tabular}{|c|c|c|c|c|}
\hline Survey Items & Mean - Male & Mean - Female & $\mathbf{t}$ & p. \\
\hline $\begin{array}{l}\text { Q1 -I possess the skill to teach students how to create } \\
\text { documents using word processing software }\end{array}$ & 4.02 & 4.41 & 2.88 & .01 \\
\hline $\begin{array}{l}\text { Q2 -I possess the skill to teach students how to format } \\
\text { documents using word processing software }\end{array}$ & 2.11 & 1.81 & 2.07 & .05 \\
\hline $\begin{array}{l}\text { Q3 -I possess the skill to teach students how to edit } \\
\text { documents using word processing software }\end{array}$ & 3.98 & 4.29 & 2.37 & .05 \\
\hline $\begin{array}{l}\text { Q5 -I possess the skill to teach students how to edit } \\
\text { documents using word processing software }\end{array}$ & 3.36 & 4.00 & 2.36 & .05 \\
\hline $\begin{array}{l}\text { Q6 - I possess the skill to teach students how to insert } \\
\text { symbols using word processing software }\end{array}$ & 3.56 & 3.94 & 2.36 &, 05 \\
\hline $\begin{array}{l}\text { Q7 -I possess the skill to teach students how to attach } \\
\text { documents }\end{array}$ & 3.59 & 4.11 & 3.03 & .01 \\
\hline
\end{tabular}

Research Question 3

Research Question 3 was: Are there any meaningful relationships, based on age, among teachers in their perceived skills to facilitate instruction using word processing, presentation, and spreadsheet software to facilitate instruction?

The participants were divided into eight groups based on age: 20-25, 26-30, 31-35, 36-40, 41-45, 46-50, 51-55, and $56 \&$ up. The researchers used an ANOVA to determine if significant differences existed for any question based on age, and Tukey HSD Post hoc tests were used to determine where the differences existed. With the exceptions Word Processing Question 8, Presentation Software Question 9, and Excel Question 5 and Question 11, significant differences were found for all questions at the $\mathrm{p}<.05$ as shown in the summary table 5 below. See Appendix 1 for detailed ANOVA analyses tables.

In most cases, the post hoc tests indicated the younger teachers, ages 20-25, had significantly higher scores than those teachers age 56+. The three lower age groups 20-25, 26-30, and 31-35 did not differ significantly from one another, and the three higher age groups 46-50, 51-55, and 56+ did not differ significantly from one another. However, for most questions the lower age groups differed significantly from the higher age groups with the lower age groups indicating that they felt more competent in using software applications in a teaching.

Table 5: Summary Findings of ANOVA Analyses Based on Age $(\mathrm{p}<.05)$

\begin{tabular}{lll}
\hline \multicolumn{3}{c}{ Differences - Significant } \\
\hline \multicolumn{1}{c}{ Word Processing } & \multicolumn{1}{c}{ Powerpoint Presentation } & \multicolumn{1}{c}{ Excel Spreadsheet } \\
\hline Q1 & Q1 & Q1 \\
Skill to teach create documents & Skill to teach proper use of software & Skill to teach format charts \\
Q2 Skill to teach format documents & Q2 & Q2 \\
& Skill to teach design templates & Skill to teach input data \\
\hline
\end{tabular}




\begin{tabular}{|c|c|c|}
\hline \multirow[t]{2}{*}{ Q3 Skill to teach edit documents } & Q3 & Q3 \\
\hline & Skill to teach resize images & Skill to teach modify data \\
\hline Q4 & Q4 & Q4 \\
\hline Skill to teach merge documents & Skill to teach change slide designs & Skill to teach create various charts \\
\hline Q5 & Q5 & Q6 \\
\hline Skill to teach layout functions & Skill to teach slide transition effects & $\begin{array}{l}\text { Skill to teach perform arithmetic } \\
\text { functions }\end{array}$ \\
\hline Q6 & Q6 & Q7 \\
\hline Skill to teach insert symbols & Skill to teach insert sounds & Skill to teach copy a range of cells \\
\hline Q7 & Q7 & Q8 \\
\hline Skill to teach attach documents & Skill to teach insert animations & $\begin{array}{l}\text { Skill to teach delete rows, columns and } \\
\text { cells }\end{array}$ \\
\hline Q9 & Q8 & Q9 \\
\hline Skill to teach drawing tools & Skill to teach insert charts & Skill to teach sort lists \\
\hline Q10 & & Q10 \\
\hline Skill to teach organize documents & & $\begin{array}{l}\text { Skill to teach analyses using formulas } \\
\text { and functions }\end{array}$ \\
\hline \multicolumn{3}{|c|}{ Differences - Not significant } \\
\hline Q8 & Q9 & Q5 \\
\hline Skill to teach tracking tools & Skill to link slides to the Internet & $\begin{array}{l}\text { Skill to teach insert rows, columns and } \\
\text { cells } \\
\text { Q11 } \\
\text { Skill to teach calculations using } \\
\text { formulas and functions }\end{array}$ \\
\hline
\end{tabular}

\section{Discussion}

Teachers' responses to 30 general software statements related to their ability to teach students to use word processing, presentation, and spreadsheet applications indicated that they did not express competence in over half of the items. They agreed that they felt competent in 14 of the 30 questions, 7 in the word processing area, 6 in the presentation area, and only 1 in the spreadsheet area. This finding supports Littrell, Zagumny and Zagumny (2005) who believe that teachers do not yet possess the skill to implement technology integration. This is rather surprising because Anderson \& Becker (2000) and Woodbridge (2004) note that public schools have been using computer technologies for over 40 years and have spent enormous amounts of money on technology, yet the integration of the basic technologies into classroom instruction still remains problematic. Keengwe, Onchwari and Wachira (2008) reported that teachers do not have confidence in using basic software applications in teaching. The authors concluded that computer integration has not been properly and effectively infused into curriculum activities. Eteokleous (2008) reported that some of the teachers who took part in her study indicated that they use technology, but remarked that such use does not include any innovative applications.

T-test in table 4 showed that female participants reported significantly higher levels of competence that males in five (question items 1, 3, 5, $6 \& 7$ ) of the ten areas of word processing. However, there were no differences based on gender for any questions in the presentation and spreadsheet applications.

The subsequent post hoc tests of the ANOVA analyses suggested that the younger teachers, aged 20-25, had significantly higher scores than those teachers aged 56+. The findings of this study adds to the literature that there was a significant difference in teachers' perceived competence in teaching software applications based on age, with younger teachers expressing more competence in using software applications in teaching their discipline area(s) than the more matured (older) teachers. Eteokleous (2008) reported that teachers still need assistance in using software applications to facilitate instruction. The findings of the present study revealed that there were differences among the age groups; the younger age groups believe that they can teach students how to use some software applications to facilitate teaching and learning while the older participants are undecided and unsure of their ability. Similar findings reported by Naquin (2000) show that the "differences in perceptions found between the younger and older professors on Loudoun campus are not surprising. The statement that produced the greatest differences in response was integrating technology into the curriculum improves learning where the responses from the older instructors tended 
to be less enthusiastically affirmative or simply neutral when compared to those of the younger instructors"

\section{Conclusion \& Recommendations}

Tsai and Chai (2012) proclaimed that when undertaking technology integration in an education context, teachers must take into account a first- and a second-order barriers, as proposed by Ertmer (in Tsai \& Chai). Failures to address these barriers can only hinder its implementation. The former barrier includes factors such as lack of adequate access, time, training and institutional support, which are "extrinsic" to teachers. The other barrier comprises more "intrinsic" factors that concern with teachers' personal, fundamental and pedagogical beliefs about integrating technology in the instructional setting. The findings of this study support the researchers' claim of a second-order barrier. The teachers who participated in this study indicated that they felt some competence in the word processing area, but little competence in presentation and spreadsheet applications. As a result, we may have foreseen an uneven weight distribution with respect to the "type" or the "form" of technology used in the instructional setting.

In addition, this study provides convincing evidence to resolve a first-order barrier (Tsai \& Chai, 2012) by identifying flaccid areas in which professional training might be beneficial. Such evidence should be brought to school administration's attention so adequate support/training can be provided. The significant differences in perceived skill competence based on age suggested that any training should accommodate and address the impact of age as related to technology training. It is recommended that training which involves peer-to-peer learning, collaborative activities, a variety of training materials, and a skilled trainer can provide a learning environment in which individual differences can be accommodated. It is important to remember that training is only one step in the learning process, it is equally important that follow-up training activities in the form of workshops be instituted in order to help teachers consolidate the skill they have acquired. A potential technology trainer can send a diagnostic questionnaire to teachers prior to the training session aimed at determining their (teachers) strengths and weaknesses so that these can be addressed during the training sessions. Therefore, it is recommended that the training materials be based on the trainees' (teachers') needs and weaknesses and not solely be determined by the trainer.

\subsection{Limitations of the Study}

The findings of this study should not be generalized to other populations. Although anonymity of the participants was assured, the findings are limited to the honesty of the participants in completing the instrument. It is possible that teachers might have responded in a way that presents them as more knowledgeable, competent, and hard working. Although the researchers strived to present a neutral view of technology integration in instructional setting, it is possible that questions were presented in such a way that developed bias based on their desire to present an effective technology-mediated instruction.

The researchers' data is limited to the responses that the participants submitted. There were no personal discussions or dialogue to draw additional data from. The lack of qualitative data is a limitation of the study.

\subsection{Implications for Further Research}

Two primary variables were examined in the study: age and gender, because both of the factors were vitally related to the participants' knowledge of computers and computer software. Female respondents had higher means scores in more questionnaire items using Word Processing software, than their male counterparts. In terms of Age, the lower age groups differed significantly for most questions from the higher age groups with the lower age groups indicating that they felt more competent in using software applications in a teaching. Variables that impact students' perceptions of infusing technology in teaching merit additional research. Models including variables not examined in this study should be considered.

\section{Acknowledgements}

This project and publication were funded in part by the National Science Council of the Republic of China (Taiwan) (NSC\# 101-2511-S-255-005-). Any opinions, findings, conclusions or recommendations expressed in this publication are those of the authors and do not necessarily reflect the views of the National Science Council. Data collection and analyses were performed by the authors of this report. The authors of this report include researchers and/or educators affiliated with private and public universities in Taiwan. Wei-Chieh Wayne Yu of the Chang Gung University of Science \& Technology, is the lead and corresponding author of this report. You may contact him at 886-988972687, or via e-mail at jamiemeetsworld@gmail.com or by mail at No.2, West Sec. Chia-Pu Rd. Pu-tz City, 
Chiayi County 613, Taiwan (R.O.C.).

\section{References}

Anderson, L. W. (2010). Computer technology integration into the public school classroom. Retrieved from http://www.academicleadership.org/pdf/ALJ_ISSN1533-7812_8_2_468.pdf

Anderson, R., \& Becker, H (2000). Instructional technology investments in US schools. Retrieved from: http://www.gse.uci.edu/doehome/deptinfor/faculty/becker/aera00/poster_19/indezx.htm

Baylor, A. L., \& Ritchie, D. (2002). What factors facilitate teacher skill, teacher moral, and perceived student learning in technology-using classrooms? Computers and Education, 39, 395-414. http://dx.doi.org/10.1016/S0360-1315(02)00075-1

Becker, H. J. (2001). How are teachers using technology in instruction? Retrieved from $\mathrm{http} / / / \mathrm{www}$. crito.uci.edu/tlc/findings/conferences-pdf/how_are_teachers_using.pdf

Casey, H. B., \& Rakes, G. C. (2002). An analysis of the influence of technology training on teachers' stages of concern regarding the use of instructional technology in schools. Journal of Computing in Teacher Education, $18(4), 124-132$.

ChanLin, L. (2007). Perceived importance and manageability of teachers toward the factors of integrating computer technology into classrooms. Innovations in Education and Teaching International, 22(1), 45-55. http://dx.doi.org/10.1080/14703290601090390

Donahoo, S., \& Whitney, M (2006). Knowing and getting what you pay for: Administration, technology, and accountability in K-12 schools. In S. Y. Tettegah \& R.C. Hunter (Eds), Technology and Education: Issues in Administration, Policy, and Applications in K12Schools Advances in Educational Administration, (Vol. 8, pp. 125-142). Elsevier. http://dx.doi.org/10.1016/S1479-3660(05)08010-8

Eteokleous, N. (2008). Evaluating computer technology integration in a centralized school system. Computers and Education, 51(12), 669-686. http://dx.doi.org/10.1016/j.compedu.2007.07.004

Franklin, C. (2007). Factors that influence elementary teachers' use of computers. Journal of Technology and Teacher Education, 15(2), 267-293.

Franklin, T., Turner, S., Kariuki, M., \& Duran, M. (2001). Mentoring overcomes barriers to technology integration. Journal of Computing in Teacher Education, 18(1), 26-31.

Fullan, M. (2001). The new meaning of educational change. New York: Teachers College Press.

Hew, K. F., \& Brush, T. (2007). Integrating technology in K-12 teaching and learning: Current knowledge gaps and recommendations for future research. Education Technology Research \& Development, 55, 223-252. http://dx.doi.org/10.1007/s11423-006-9022-5

Jiang, W. W., Chen, W., \& Chen, Y. C. (2004). Important computer competencies for the nursing profession. Journal of Nursing Research, 12(3), 213-216. http://dx.doi.org/10.1097/01.JNR.0000387505.98877.6d

Keengwe, J., Onchwari, G., \& Wachira, P. (2008).Computer technology integration and student learning: Barriers and promise. Journal of Science Education \& Technology, 17(6), 56-565. http://dx.doi.org/10.1007/s10956-008-9123-5

Knowles, S., Elwood, F. H. III., \& Richard, A. S. (1998). The adult learner. Houston: Gulf Publishing.

Lee, T. T. (2005). Nursings' concerns about using information systems: Analysis of comments on a computerized nursing care plan system in Taiwan. Journal of Clinical Nursing, 14(3), 344-353. http://dx.doi.org/10.1111/j.1365-2702.2004.01060.x

Littrell, A. B., Zagumny, M. J., \& Zagumny, L. L. (2005). Contextual and psychological predictors of instructional technology use in rural classrooms. Educational Research Quarterly, 29(2), 37-47.

Okojie, M.C.P O., Boulder, T. C., \& Boulder, J. (2011). Teachers Perception of their preferred instructional methods in technology training sessions. Leadership in Teaching and Learning, 6(1), 56-67.

Okojie, M. C. P. O., Olinzock, A. A., \& Okojie-Boulder, T. C. (2006). The pedagogy of technology integration. Journal of Technology Studies, 32(2), 66-71.

Naquin, D. (2000). The integration of technology at Loudoun campus, Northern Virginia Community College: A 


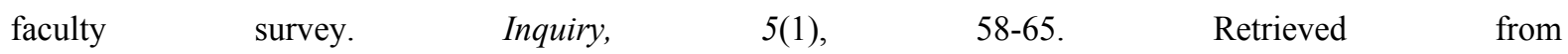
http://www.aedu..org/inquiry/inquiry-spring2000/i-51-naquin.html

National Council on Education Statistics. (2002). The nation's report card: U.S. history 2001. Retrieved from http://www.mindfully.org/Reform/2002/Nations-Report-Card-US-HistoryMay02.htm

Roberts, B. S. (2003). Using computers and technology in the social studies classroom: A study of practical pedagogy. Unpublished doctoral dissertation, Georgia State University Atlanta.

Ronnkvist, A., Dexter, S., \& Anderson, R. (2000). Technology support: Its depth, breadth and impact in America's schools. Retrieved from http://www.crito.uci.edu/tlc/findings/technology-support/report_5.pdf

Shulman, L. (1986). Those who understand: Knowledge growth in teaching. Educational researcher, 15(2), 4-14. http://dx.doi.org/10.3102/0013189X015002004

Tsai, C. C., \& Chai, C. S. (2012). The "third"-order barrier for technology-integration instruction: Implications for teacher education. Australasian Journal of Education Technology, 28(6), 1057-1060.

Zuniga, R. (2010). Computer technology integration into the public school classroom, academic leadership: A qualitative update. The Online Journal, 8(2), 1-17. Retrieve from http://www.academicleadership.org/pdf/ALJ_ISSN1533-7812_8_2_468.pdf

Wilmore, D., \& Betz, M. (2000). Information technology and schools: The principal's role. Educational Technology and Society, 3(4), 12-19. Retrieved from http://www.tojet.net/articles/749.pdf

Woodbridge, J. (2004). Technology integration as a transforming teaching strategy. Retrieved from http://www.techlearning.com/shared/printableArticle.php?articleID=17701367

Yang, Y., \& Lin, N. C. (2010). Internet perceptions, online participation and language learning in Moodle forums: A case study on nursing students in Taiwan. Procedia-Social and Behavioral Sciences, 2(2), 2647-2651. http://dx.doi.org/10.1016/j.sbspro.2010.03.388

Zhao, Y., \& Bryant, F. L. (2005). Can teacher technology integration training alone lead to high levels of technology integration? A qualitative look at teachers' technology integration after state mandated technology training. Electronic Journal for the Integration of Technology in Education, 5, 53-62.

Zuniga, R. (2010). Computer Technology Integration into the Public School Classroom, Academic Leadership: A qualitative update. The Online Journal, 8(2), 1-17. Retrieve from http://www.academicleadership.org/pdf/ALJ_ISSN1533-7812_8_2_468.pdf 


\section{Appendix 1-ANOVA Tables Based on Age}

Word Processing

\begin{tabular}{|c|c|c|c|c|c|c|}
\hline & & $\begin{array}{l}\text { Sum of } \\
\text { Squares }\end{array}$ & $\mathrm{df}$ & $\begin{array}{l}\text { Mean } \\
\text { Square }\end{array}$ & $\mathrm{F}$ & Sig. \\
\hline Word Processing, & Between Groups & 38.160 & 7 & 5.451 & 7.116 & .000 \\
\hline Q1 & Within Groups & 229.059 & 299 & .766 & & \\
\hline Skill to teach create documents & Total & 267.218 & 306 & & & \\
\hline Q2 & Between Groups & 46.490 & 7 & 6.641 & 6.613 & .000 \\
\hline \multirow[t]{2}{*}{ Skill to teach format documents } & Within Groups & 301.302 & 300 & 1.004 & & \\
\hline & Total & 347.792 & 307 & & & \\
\hline Q3 & Between Groups & 38.143 & 7 & 5.449 & 6.682 & .000 \\
\hline \multirow[t]{2}{*}{ Skill to teach edit documents } & Within Groups & 245.449 & 301 & .815 & & \\
\hline & Total & 283.592 & 308 & & & \\
\hline Q4 & Between Groups & 59.643 & 7 & 8.520 & 6.711 & .000 \\
\hline \multirow[t]{2}{*}{ Skill to teach merge documents } & Within Groups & 380.877 & 300 & 1.270 & & \\
\hline & Total & 440.519 & 307 & & & \\
\hline Q5 & Between Groups & 32.183 & 7 & 4.598 & 3.231 & .003 \\
\hline \multirow[t]{2}{*}{ Skill to teach layout functions } & Within Groups & 421.238 & 296 & 1.423 & & \\
\hline & Total & 453.421 & 303 & & & \\
\hline Q6 & Between Groups & 27.881 & 7 & 3.983 & 2.765 & .008 \\
\hline \multirow[t]{2}{*}{ Skill to teach insert symbols } & Within Groups & 429.272 & 298 & 1.441 & & \\
\hline & Total & 457.154 & 305 & & & \\
\hline Q7 & Between Groups & 50.119 & 7 & 7.160 & 4.954 & .000 \\
\hline \multirow[t]{2}{*}{ Skill to teach attach documents } & Within Groups & 427.763 & 296 & 1.445 & & \\
\hline & Total & 477.882 & 303 & & & \\
\hline Q8 & Between Groups & 23.886 & 7 & 3.412 & 2.259 & .300 \\
\hline \multirow[t]{2}{*}{ Skill to teach tracking tools } & Within Groups & 450.052 & 298 & 1.510 & & \\
\hline & Total & 473.938 & 305 & & & \\
\hline Q9 & Between Groups & 37.649 & 7 & 5.378 & 3.179 & .003 \\
\hline \multirow[t]{2}{*}{ Skill to teach drawing tools } & Within Groups & 504.233 & 298 & 1.692 & & \\
\hline & Total & 541.882 & 305 & & & \\
\hline Q10 & Between Groups & 41.245 & 7 & 5.892 & 5.059 & .000 \\
\hline \multirow[t]{2}{*}{ Skill to teach organize documents } & Within Groups & 348.234 & 299 & 1.165 & & \\
\hline & Total & 389.479 & 306 & & & \\
\hline $\mathrm{p}<.05$ & & & & & & \\
\hline
\end{tabular}




\section{Powerpoint Presentation}

\begin{tabular}{|c|c|c|c|c|c|c|}
\hline & & $\begin{array}{l}\text { Sum of } \\
\text { Squares }\end{array}$ & df & $\begin{array}{l}\text { Mean } \\
\text { Square }\end{array}$ & $\mathrm{F}$ & Sig. \\
\hline Presentation Software & Between Groups & 77.190 & 7 & 11.027 & 8.889 & .000 \\
\hline Q1 & Within Groups & 370.907 & 306 & 1.240 & & \\
\hline Skill to teach proper use of software & Total & 448.098 & 313 & & & \\
\hline Q2 & Between Groups & 69.451 & 7 & 9.922 & 7.756 & .000 \\
\hline \multirow[t]{2}{*}{ Skill to teach design templates } & Within Groups & 382.471 & 306 & 1.279 & & \\
\hline & Total & 451.922 & 313 & & & \\
\hline Q3 & Between Groups & 42.519 & 7 & 6.074 & 3.672 & .001 \\
\hline \multirow[t]{2}{*}{ Skill to teach resize images } & Within Groups & 492.922 & 306 & 1.654 & & \\
\hline & Total & 535.441 & 313 & & & \\
\hline Q4 & Between Groups & 77.162 & 7 & 11.023 & 7.103 & .000 \\
\hline \multirow[t]{2}{*}{ Skill to teach change slide designs } & Within Groups & 459.387 & 306 & 1.552 & & \\
\hline & Total & 536.549 & 313 & & & \\
\hline Q5 & Between Groups & 76.532 & 7 & 10.933 & 7.965 & .000 \\
\hline \multirow[t]{2}{*}{ Skill to teach slide transition effects } & Within Groups & 409.027 & 306 & 1.373 & & \\
\hline & Total & 485.559 & 313 & & & \\
\hline Q6 & Between Groups & 67.773 & 7 & 9.682 & 5.755 & .000 \\
\hline \multirow[t]{2}{*}{ Skill to teach insert sounds } & Within Groups & 496.273 & 306 & 1.682 & & \\
\hline & Total & 564.046 & 313 & & & \\
\hline Q7 & Between Groups & 67.964 & 7 & 9.709 & 5.965 & .000 \\
\hline \multirow[t]{2}{*}{ Skill to teach insert animations } & Within Groups & 481.773 & 306 & 1.628 & & \\
\hline & Total & 549.737 & 313 & & & \\
\hline Q8 & Between Groups & 30.443 & 7 & 4.349 & 2.768 & .008 \\
\hline \multirow[t]{2}{*}{ Skill to teach insert charts } & Within Groups & 466.586 & 306 & 1.571 & & \\
\hline & Total & 497.030 & 313 & & & \\
\hline Q9 & Between Groups & 88.785 & 7 & 12.684 & 9.519 & .481 \\
\hline \multirow[t]{2}{*}{ Skill to link slides to the Internet } & Within Groups & 395.753 & 306 & 1.333 & & \\
\hline & Total & 484.538 & 313 & & & \\
\hline $\mathrm{p}<.05$ & & & & & & \\
\hline
\end{tabular}




\section{Excel Spreadsheet}

\begin{tabular}{|c|c|c|c|c|c|c|}
\hline & & $\begin{array}{l}\text { Sum of } \\
\text { Squares }\end{array}$ & $\mathrm{df}$ & $\begin{array}{l}\text { Mean } \\
\text { Square }\end{array}$ & $\mathrm{F}$ & Sig. \\
\hline Spreadsheet Software & Between Groups & 47.450 & 7 & 6.779 & 4.037 & .000 \\
\hline Q1 & Within Groups & 497.020 & 306 & 1.679 & & \\
\hline Skill to teach format charts & Total & 544.470 & 313 & & & \\
\hline Q2 & Between Groups & 44.124 & 7 & 6.303 & 3.787 & .001 \\
\hline \multirow[t]{2}{*}{ Skill to teach input data } & Within Groups & 494.388 & 306 & 1.665 & & \\
\hline & Total & 538.511 & 313 & & & \\
\hline Q3 & Between Groups & 33.766 & 7 & 4.824 & 2.682 & .010 \\
\hline \multirow[t]{2}{*}{ Skill to teach modify data } & Within Groups & 532.339 & 306 & 1.798 & & \\
\hline & Total & 566.105 & 313 & & & \\
\hline Q4 & Between Groups & 42.066 & 7 & 6.009 & 3.488 & .001 \\
\hline \multirow[t]{2}{*}{ Skill to teach create various charts } & Within Groups & 509.905 & 306 & 1.723 & & \\
\hline & Total & 551.970 & 313 & & & \\
\hline Q5 & Between Groups & 14.292 & 7 & 2.042 & 1.183 & .312 \\
\hline Skill to teach insert rows, columns & Within Groups & 512.659 & 306 & 1.726 & & \\
\hline and cells & Total & 526.951 & 313 & & & \\
\hline Q6 & Between Groups & 47.384 & 7 & 6.769 & 3.965 & .000 \\
\hline Skill to teach perform arithmetic & Within Groups & 505.353 & 306 & 1.707 & & \\
\hline functions & Total & 552.737 & 313 & & & \\
\hline Q7 & Between Groups & 65.066 & 7 & 9.295 & 5.763 & .000 \\
\hline \multirow[t]{2}{*}{ Skill to teach copy a range of cells } & Within Groups & 479.046 & 306 & 1.613 & & \\
\hline & Total & 544.111 & 313 & & & \\
\hline Q8 & Between Groups & 58.878 & 7 & 8.411 & 4.919 & .000 \\
\hline Skill to teach delete rows, columns & Within Groups & 506.171 & 306 & 1.710 & & \\
\hline and cells & Total & 565.049 & 313 & & & \\
\hline Q9 & Between Groups & 29.339 & 7 & 4.191 & 2.567 & .014 \\
\hline \multirow[t]{2}{*}{ Skill to teach sort lists } & Within Groups & 486.608 & 306 & 1.633 & & \\
\hline & Total & 515.948 & 313 & & & \\
\hline Q10 & Between Groups & 43.051 & 7 & 6.150 & 3.703 & .001 \\
\hline Skill to teach analyses using formulas & Within Groups & 484.949 & 306 & 1.661 & & \\
\hline and functions & Total & 528.000 & 313 & & & \\
\hline Q11 & Between Groups & 16.463 & 7 & 2.352 & 1.241 & .28 \\
\hline Skill to teach calculations using & & & & & & 1 \\
\hline \multirow[t]{2}{*}{ formulas and functions } & Within Groups & 557.355 & 306 & 1.896 & & \\
\hline & Total & 573.818 & 313 & & & \\
\hline $\mathrm{p}<.05$ & & & & & & \\
\hline
\end{tabular}

